\title{
Mediastinal Germ Cell Tumor TNM
}

Finding

National Cancer Institute

\section{Source}

National Cancer Institute. Mediastinal Germ Cell Tumor TNM Finding. NCI Thesaurus.

Code C146826.

A TNM finding about one or more characteristics of a mediastinal germ cell tumor. This is not an official UICC TNM classification. (WHO Classification of Tumors of the Lung, Pleura, Thymus and Heart, 2015) 